Supporting Information

\title{
Anodized Aluminum Oxide Separators with Aligned Channels for High-Performance Li-S Batteries
}

Bo Wang, Wei Guo, ${ }^{*}$ and Yongzhu Fu*

College of Chemistry, Zhengzhou University, Zhengzhou 450001, P. R. China

*Corresponding authors

E-mail addresses: yfu@zzu.edu.cn (Y. Fu), weiguo@zzu.edu.cn (W. Guo)

Keywords: lithium-sulfur battery, anodized aluminum oxide, separator, electroosmotic flow, areal specific resistance

\section{Supporting figures and tables:}

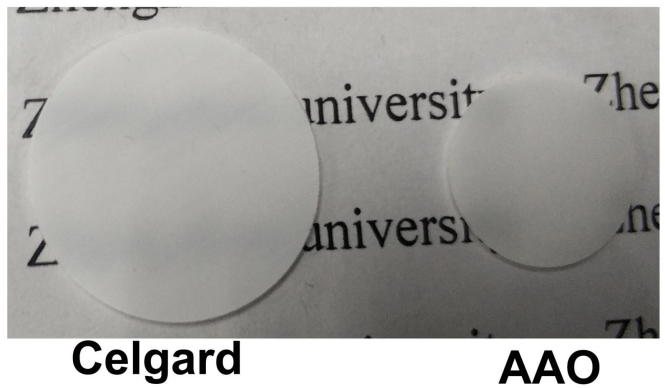

Room temperature

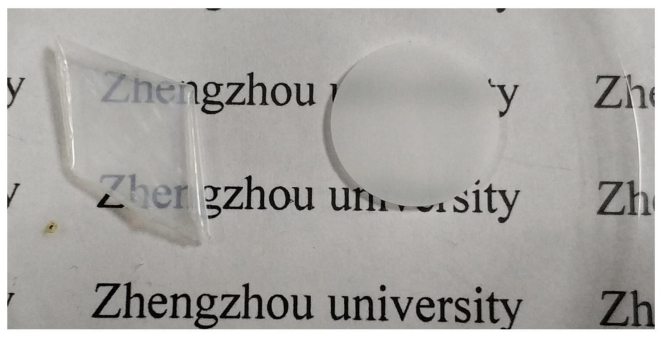

$150{ }^{\circ} \mathrm{C}$ for $30 \mathrm{~min}$

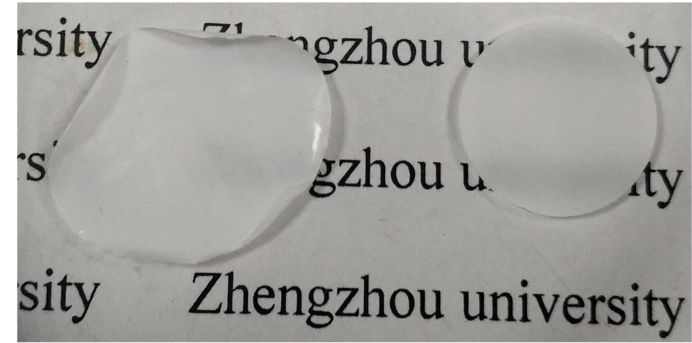

$130{ }^{\circ} \mathrm{C}$ for $30 \mathrm{~min}$

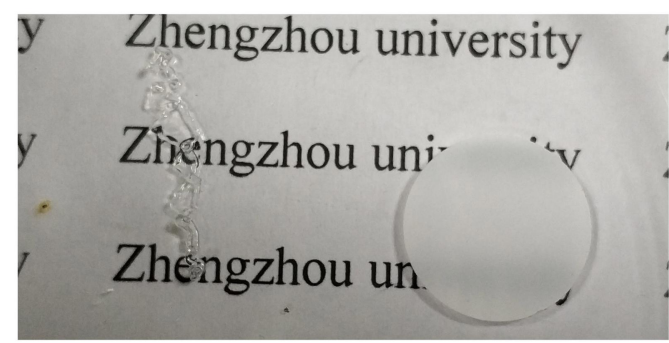

$170{ }^{\circ} \mathrm{C}$ for $30 \mathrm{~min}$

Figure S1. Thermal stability of a Celgard separator and AAO membrane at different temperatures, they were heated for $30 \mathrm{~min}$ at each temperature. The AAO membrane retains its original shape at all the temperatures, however the Celgard separator shrinks when the temperature is above $100{ }^{\circ} \mathrm{C}$. 

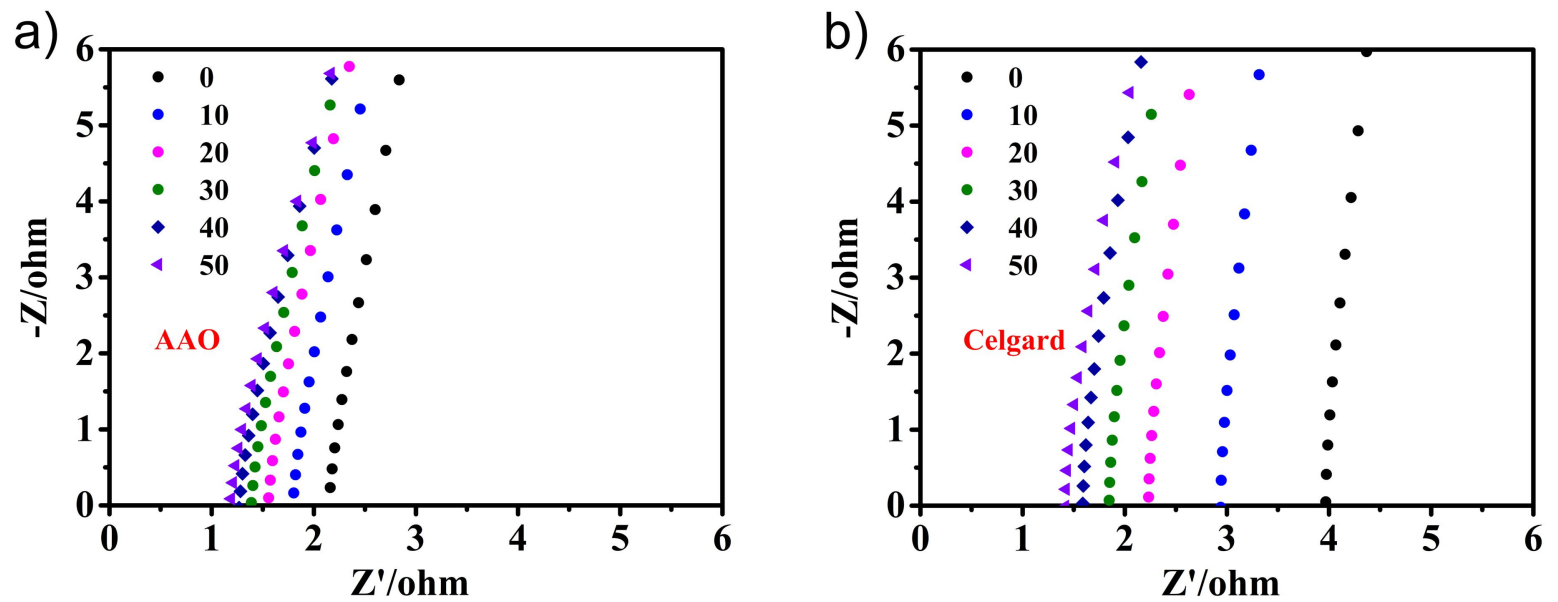

Figure S2. Nyquist plots of the AAO and Celgard separators with Li-S liquid electrolyte at different temperatures, the values in the figures are temperatures.
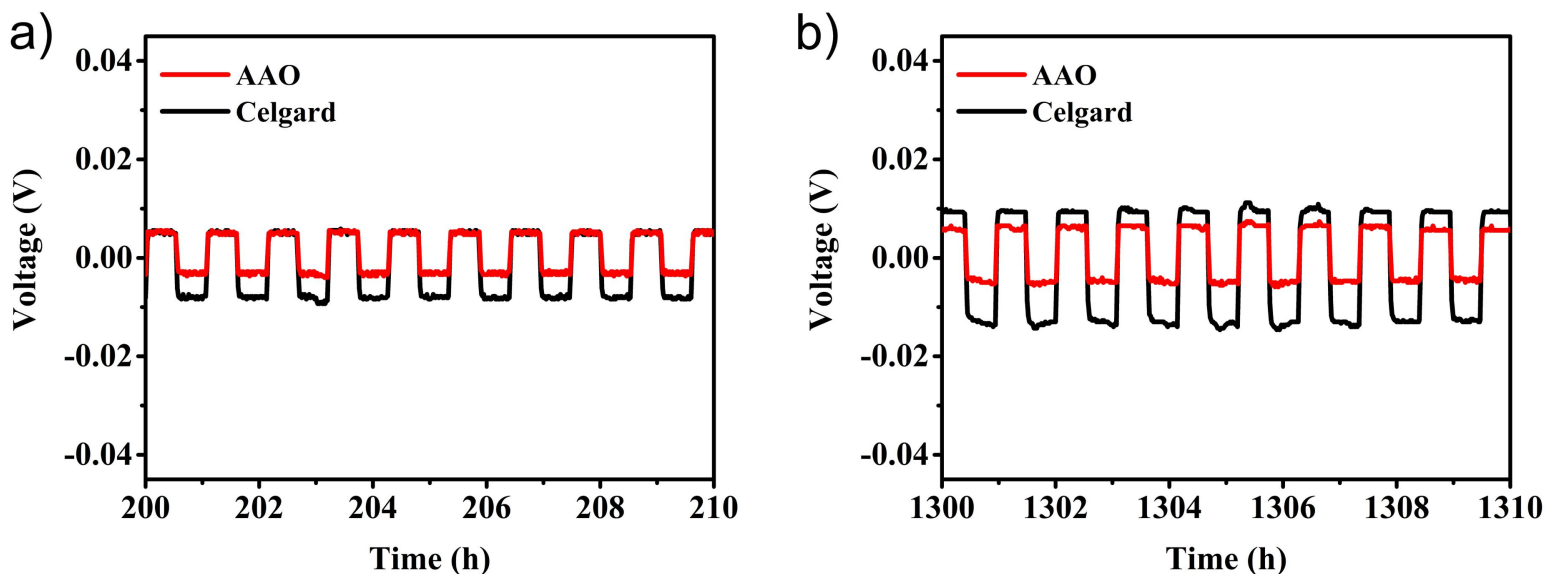

Figure S3. Selected voltage profiles of the Li symmetrical cells with different separators at the current of $0.05 \mathrm{~mA}$. 

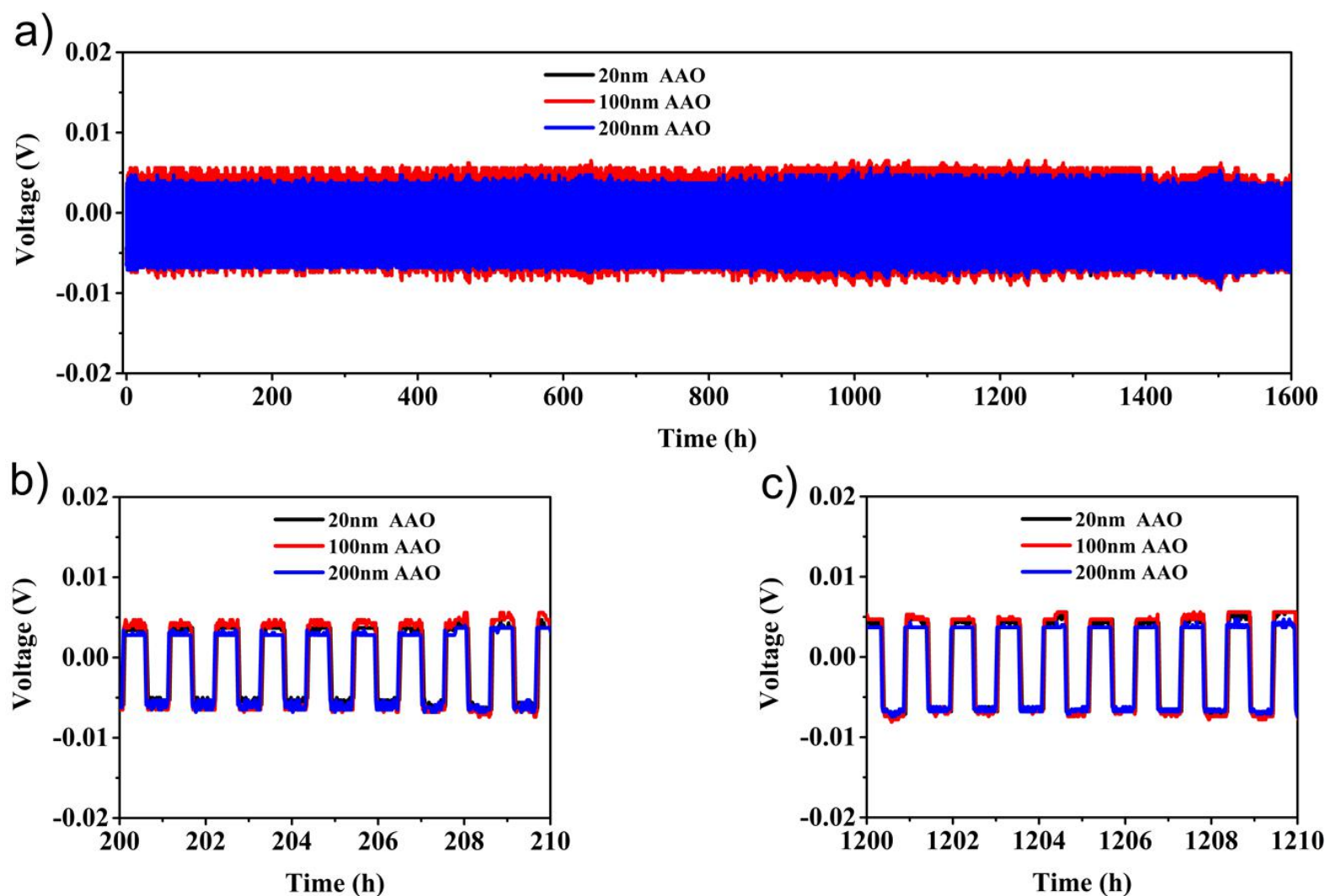

Figure S4. Voltage profiles of the Li symmetrical cells with different AAO separators at the current of $0.05 \mathrm{~mA}$.

a)

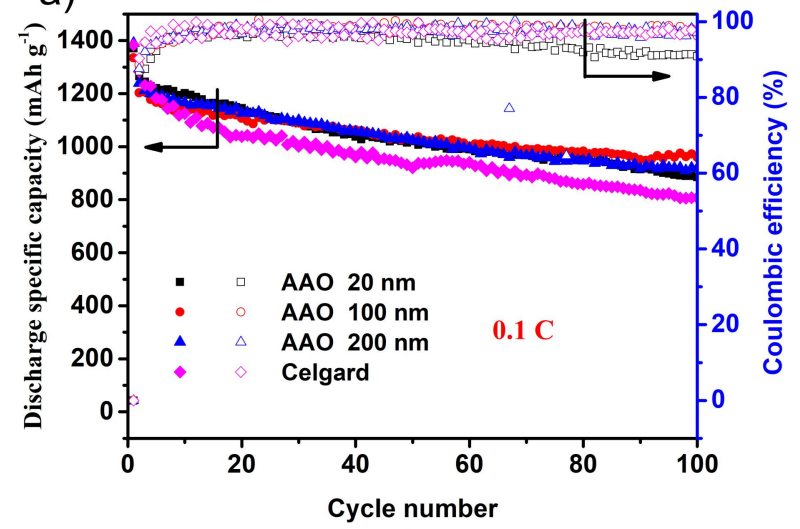

b)

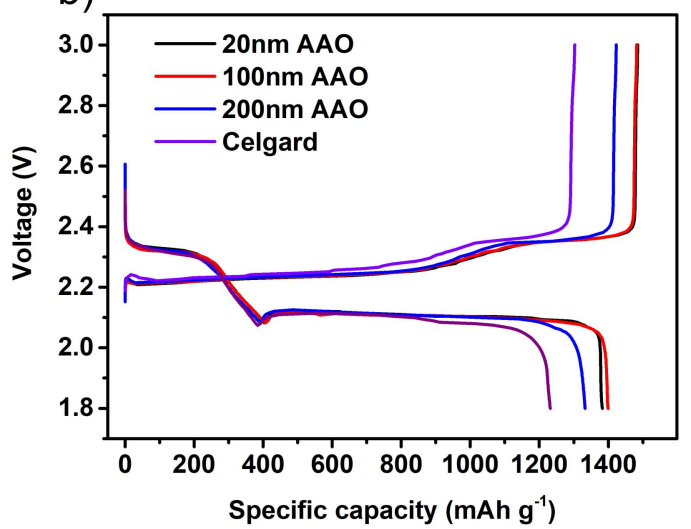

Figure S5. Cycling performance of Li-S cells using AAO separators with different pore diameters. 


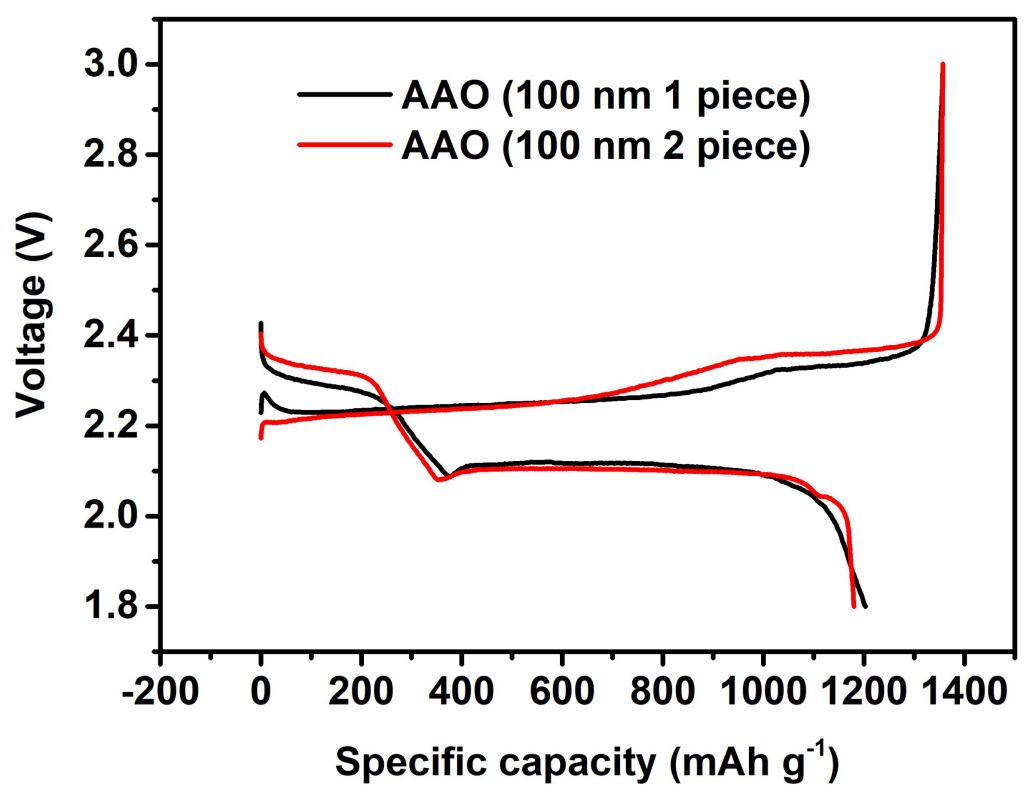

Figure S6. Voltage profiles of Li-S cells with one or two pieces of AAO separators.

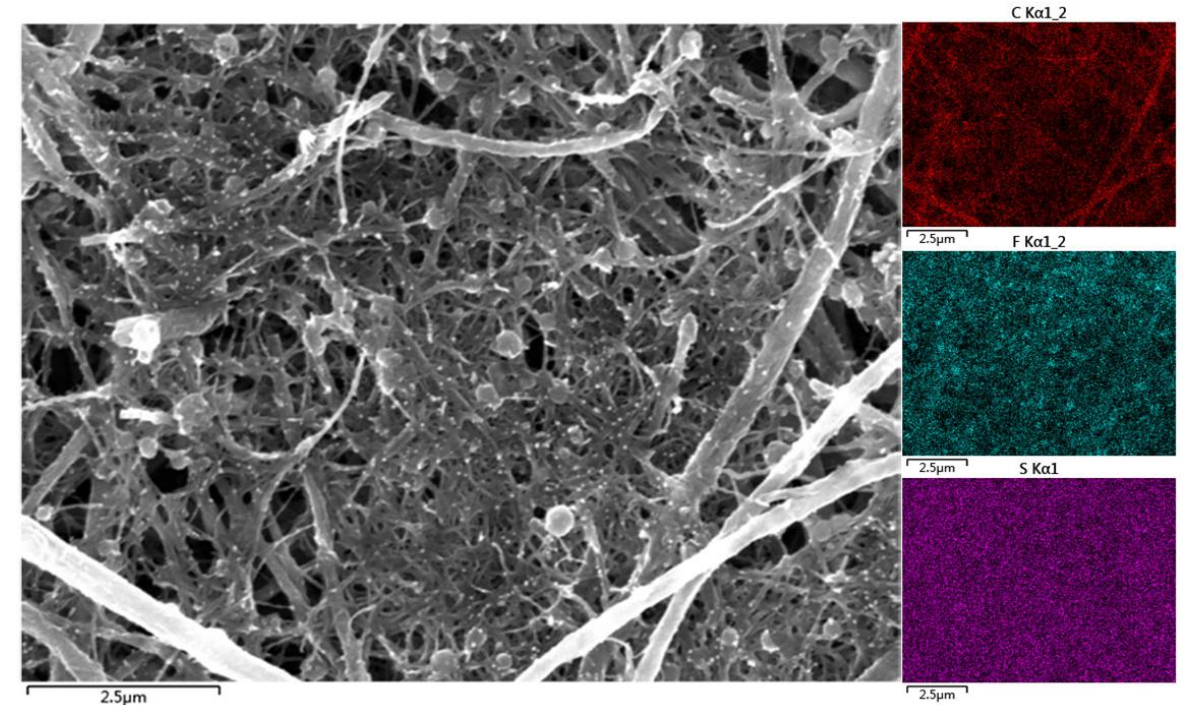

Figure S7. SEM and EDS images of the sulfur cathode after cycles with an AAO separator. 

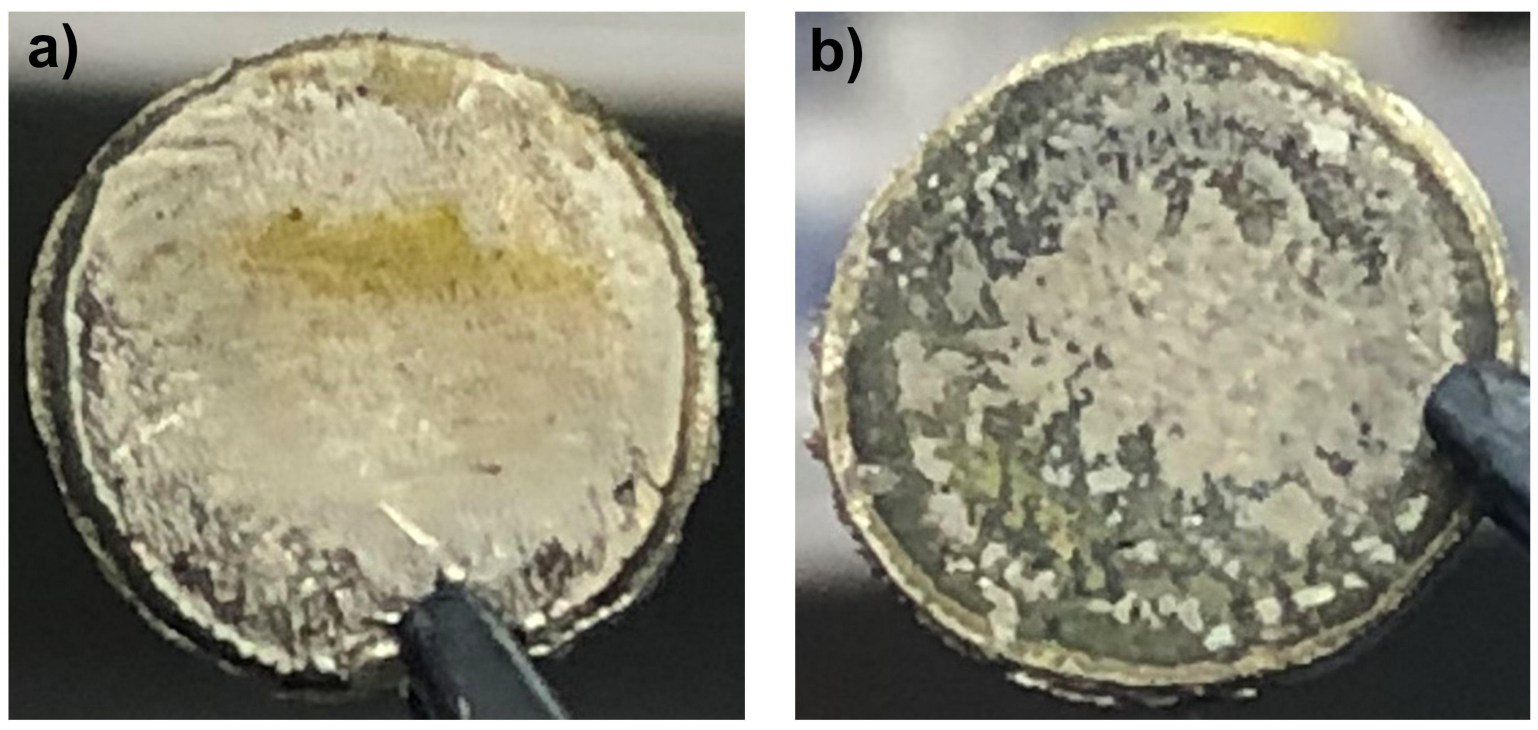

Figure S8. Optical images of the cycled Li anodes in Li-S cells with a Celgard a) or AAO separator b).

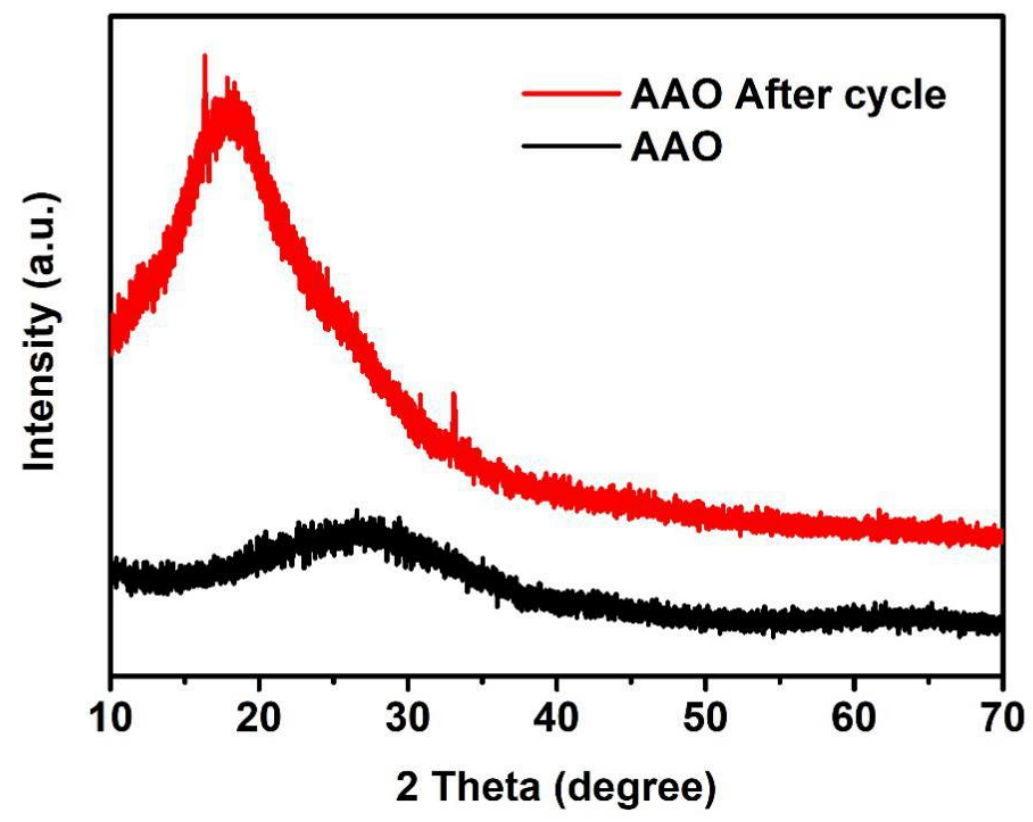

Figure S9. XRD patterns of the AAO separator before and after cycles in Li-S cells. 


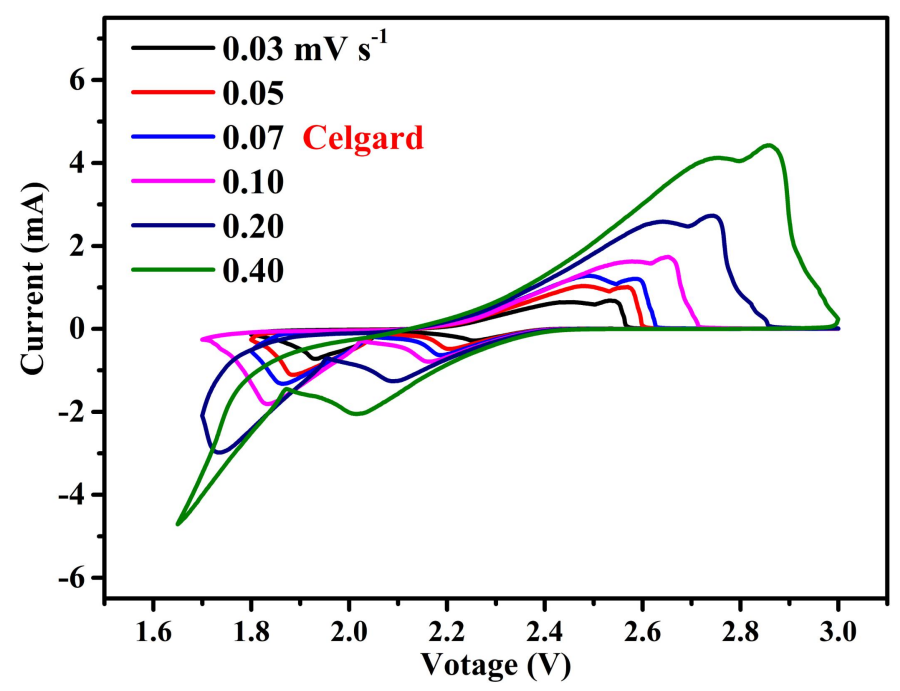

Figure S10. Cyclic voltammograms of the Li-S cell with a Celgard separator at different scanning rates. The scanning rates are $0.03,0.05,0.07,0.10,0.20$, and $0.40 \mathrm{mV} \mathrm{s}^{-1}$.

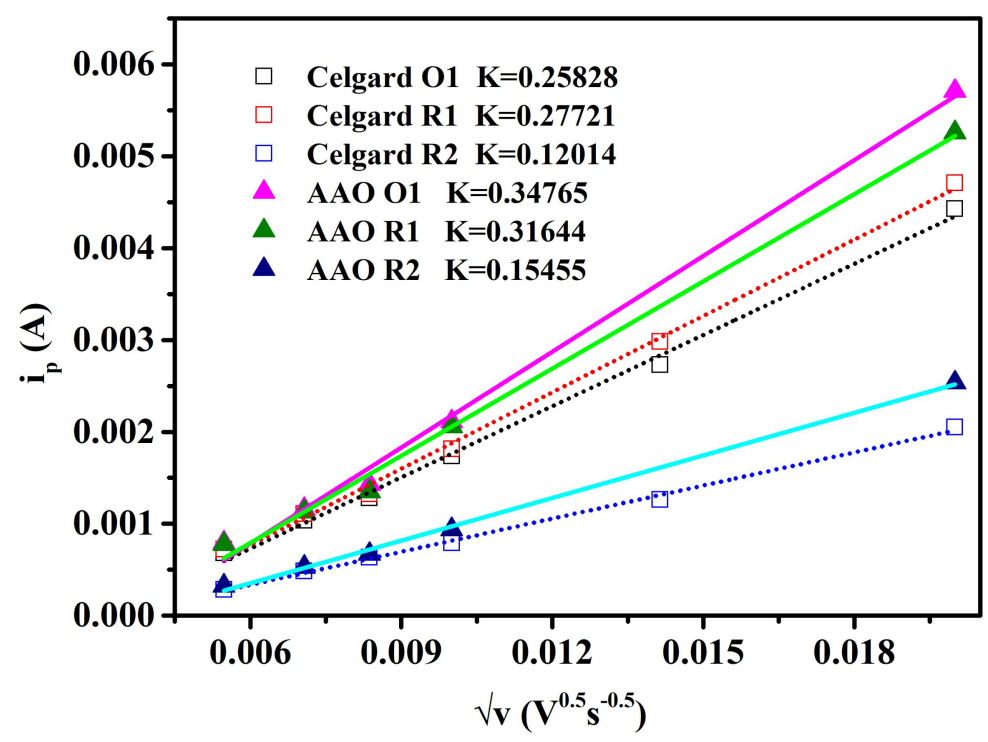

Figure S11. The linear fits between peak currents and square root of scanning rate for redox peaks in the Li-S cells with AAO and Celgard separators. 
Table S1. Liquid uptakes and porosities of AAO membranes with different pore diameters.

\begin{tabular}{|c|c|c|c|c|}
\hline $\begin{array}{c}\text { Pore diameter of } \\
\text { AAO }\end{array}$ & $\begin{array}{c}\text { Weight } \\
\text { (AAO) }\end{array}$ & $\begin{array}{c}\text { Weight (after } \\
\text { soaking with water) }\end{array}$ & $\begin{array}{c}\text { Weight (water } \\
\text { uptake) }\end{array}$ & Porosity (\%) \\
\hline $20 \mathrm{~nm}$ & $12.8 \mathrm{mg}$ & $15.1 \mathrm{mg}$ & $2.3 \mathrm{mg}$ & 28.9 \\
\hline $100 \mathrm{~nm}$ & $10.0 \mathrm{mg}$ & $14.0 \mathrm{mg}$ & $4.0 \mathrm{mg}$ & 50.2 \\
\hline $200 \mathrm{~nm}$ & $8.1 \mathrm{mg}$ & $12.6 \mathrm{mg}$ & $4.5 \mathrm{mg}$ & 56.5 \\
\hline
\end{tabular}

Table S2. Comparison of Li-S batteries with different separators.

\begin{tabular}{|c|c|c|c|c|c|c|}
\hline Separator & $\begin{array}{l}\text { Sulfur } \\
\text { cathode }\end{array}$ & $\begin{array}{l}\text { S loading } \\
\left(\mathrm{mg} \mathrm{cm}^{-2}\right)\end{array}$ & $\mathrm{C}$ rate & $\begin{array}{c}\text { Initial and end } \\
\text { discharge capacity } \\
\left(\mathrm{mAh} \mathrm{g}^{-1}\right)\end{array}$ & $\begin{array}{l}\text { Number } \\
\text { of cycles }\end{array}$ & Refs. \\
\hline PIN & $\mathrm{Li}_{2} \mathrm{~S}_{6}$ & 2 & $0.1 \mathrm{C}$ & 1100 and 794 & 200 & 1 \\
\hline $\begin{array}{c}\mathrm{Mo}_{2} \mathrm{~S} \\
\text { deposited } \\
\text { Celgard } \\
\end{array}$ & $\mathrm{CNF} / \mathrm{Li}_{2} \mathrm{~S}_{8}$ & 2.3 & $0.5 \mathrm{C}$ & 1010 and 555 & 400 & 2 \\
\hline $\begin{array}{l}\text { PMMA } \\
\text { Celgard }\end{array}$ & $\mathrm{AB} / \mathrm{S}$ & 0.55 & $0.11 \mathrm{C}$ & 1100 and 613 & 100 & 3 \\
\hline $\begin{array}{l}\text { UiO-66-S/ } \\
\text { Nafion } \\
\text { separators }\end{array}$ & $\mathrm{rGO} / \mathrm{S}$ & 1.7 & $0.1 \mathrm{C}$ & 1127 and 872 & 200 & 4 \\
\hline LLZTO & $\mathrm{CNT} / \mathrm{S}$ & 1 & $0.2 \mathrm{C}$ & 1110 and 841 & 50 & 5 \\
\hline LLZTO & $\mathrm{CNT} / \mathrm{S}$ & 1 & $0.5 \mathrm{C}$ & 649 and 537 & 500 & 5 \\
\hline $\begin{array}{l}\text { Spiderweb } \\
\text { separator }\end{array}$ & $\mathrm{CB} / \mathrm{S}$ & l & $2 \mathrm{C}$ & 820 and 540 & 300 & 6 \\
\hline AAO & $\mathrm{CNF} / \mathrm{S}$ & 1.2 & $0.1 \mathrm{C}$ & 1384 and 807 & 100 & $\begin{array}{l}\text { This } \\
\text { work }\end{array}$ \\
\hline $\mathrm{AAO}$ & $\mathrm{CNF} / \mathrm{S}$ & 1.2 & $2 \mathrm{C}$ & 786 and 396 & 480 & $\begin{array}{l}\text { This } \\
\text { work }\end{array}$ \\
\hline
\end{tabular}




\section{References:}

(1) Yu, X.; Feng, S.; Boyer, M. J.; Lee, M.; Ferrier, R. C.; Lynd, N. A.; Hwang, G. S.; Wang, G.; Swinnea, S.; Manthiram, A. Controlling the Polysulfide Diffusion in Lithium-Sulfur Batteries with a Polymer Membrane with Intrinsic Nanoporosity. Mater. Today Energy 2018, 7, 98-104.

(2) Yu, X.; Zhou, G.; Cui, Y. Mitigation of Shuttle Effect in Li-S Battery Using a Self-Assembled Ultrathin Molybdenum Disulfide Interlayer. ACS Appl. Mater. Interfaces 2019, 11, 3080-3086.

(3) Deng, C.; Wang, Z.; Wang, S.; Yu, J.; Martin, D. J.; Nanjundan, A. K.; Yamauchi, Y. Double-Layered Modified Separators as Shuttle Suppressing Interlayers for Lithium-Sulfur Batteries. ACS Appl. Mater. Interfaces 2019, 11, 541-549.

(4) Kim, S. H.; Yeon, J. S.; Kim, R.; Choi, K. M.; Park, H. S. A functional separator coated with sulfonated metal-organic framework/Nafion hybrids for Li-S batteries. J. Mater. Chem. A 2018, 6, 24971-24978.

(5) Qu, H.; Ju, J.; Chen, B.; Xue, N.; Du, H.; Han, X.; Zhang, J.; Xu, G.; Yu, Z.; Wang, X.; Cui, G. Inorganic separators enable significantly suppressed polysulfide shuttling in high-performance lithium-sulfur batteries. J. Mater. Chem. A 2018, 6, 23720-23729.

(6) Lee, Y.-H.; Kim, J.-H.; Kim, J.-H.; Yoo, J.-T.; Lee, S.-Y. Spiderweb-Mimicking Anion-Exchanging Separators for Li-S Batteries. Adv. Funct. Mater. 2018, 28, 1801422. 